\title{
Removal of 2-Nitrophenol by Linde Type A (LTA) zeolites
}

\author{
T. Kalaycı ${ }^{1}$, B. Bardakçı ${ }^{1}$ and N. K. Kınaytürk \\ ${ }^{1}$ Physics Department, Faculty of Arts and Sciences, Mehmet Akif Ersoy University, 15030, Burdur, Turkey. \\ ${ }^{2}$ Experimental and Observation Research and Application Centre, Suleyman Demirel University, West Campus, \\ 32260, Isparta, Turkey. \\ Accepted 02 January, 2013 \\ The adsorption of 2-nitrophenol on zeolites $3 A(K A)$ and $5 A(\mathrm{CaA})$, the general name of which is \\ Linde Type A (LTA), have been investigated by using fourier transform infrared (FT-IR) \\ spectroscopy and scanning electron microscope (SEM) analysis. Nitrophenols can be regarded \\ as both occupational and environmental pollutants. In this work, LTA zeolites which are \\ commercially suitable media for environmental pollutants are used to remove nitrophenols. FT- \\ IR spectroscopy can give useful and often definitive information on the structure and surface \\ properties of zeolite before and after the adsorption. The spectral data showed that the source \\ of adsorption of the 2-nitrophenol on zeolites $3 A$ and $5 A$ is the interaction between the hydroxyl \\ $(\mathrm{OH})$ group of the adsorbent and the surface silanol groups of the zeolites by means of a \\ hydrogen bond.
}

Key words: Adsorption, Linde Type A (LTA) zeolites, 2-nitrophenol, IR spectroscopy.

\section{INTRODUCTION}

Zeolites are widely known as molecular sieves. Considering the penetration and adsorption of molecules onto the zeolite channels are important. This is shown in the investigation of adsorption onto zeolites using molecular spectroscopic procedures (Little, 1966). Phenols and phenolic compounds are a kind of typical organic contaminants in wastewaters and drinking water. These contaminants are generated from a number of industrial manufacturing processes such as pesticide, paint, solvent, pharmaceutical, wood preserving chemicals, and pulp industries (Pi et al., 2007). Specific adsorbents are used for the removal of phenols from aqueous solution (Abburi, 2003; Furuya et al., 1997; Dargaville et al., 1996; Shu et al., 1997; Ku and Lee, 2000; Dutta et al., 2001; Shen, 2002; Denizli et al., 2001).

Nitrophenols are of interest due to their inclusion as priority toxic pollutants by agencies such as the United States Environmental Protection Agency. The industrial growth and population increase have resulted in the release of different pollutants in the

\footnotetext{
${ }^{*}$ Corresponding author. $\quad$ E-mail: bbardakci@mehmetakif.edu.tr. Tel: + 902482133029. Fax: + 902482133099 .
}

environment and the treatment of effluents has become a challenging topic in environmental sciences (Ely et al., 2009).

Synthetic zeolites are interesting from the point view of their usability as efficient adsorbents for removal of many pollutants from the environment (Bardakçi and Kaya, 2009; Abu-Lail, 2010). Because aromatic nitro compounds represent a group of highly toxic pollutants, study of the method of their removal from environment represents the highest degree of interest in environmental technologies.

Adsorption is an effective technique for removing low level of organic pollutants out of drinking water, waste water, and other aqueous solutions. Toxic organic pollutants such as phenolic compounds can effectively be removed by means of adsorption. In this study, the adsorption of 2-nitrophenol on $3 \mathrm{~A}$ and $5 \mathrm{~A}$ zeolites are examined by infrared spectroscopy and scanning electron microscopy (SEM).

\section{EXPERIMENTAL}

$3 \mathrm{~A}$ and $5 \mathrm{~A}$ zeolites are chosen by the facility of same structure but different cavity sizes which allows comparing their adsorption characteristics. The synthetic zeolites KA (type 3A), and $\mathrm{CaA}$ (type $5 \mathrm{~A}$ ) were obtained from the Aldrich Chemical Company. The unit cells of zeolites contain: 


\section{$2-\mathrm{NO}_{2} \mathrm{PhOH}$}



Figure 1. Schematic representation of zeolite-2-nitrophenol interaction.

$\mathrm{M}_{12}\left[\left(\mathrm{AlO}_{2}\right)_{12}\left(\mathrm{SiO}_{2}\right)_{12}\right] \cdot 27 \mathrm{H}_{2} \mathrm{O}$

Where, $\mathrm{M}=\mathrm{K}$, or $\mathrm{Ca}$.

2-nitrophenol $\left(\mathrm{HOC}_{6} \mathrm{H}_{4} \mathrm{NO}_{2}\right)$ was used without purification. As for the preparation of the samples, the mentioned zeolites were activated at $623 \mathrm{~K}$ for 4 hands then $0.1 \mathrm{~g}$ of each zeolite was placed into $40 \mathrm{mg}$ of 2-nitrophenol. After stirring and storing for $72 \mathrm{~h}$, the mixtures were filtered and washed twice with ethyl alcohol to remove the residues and then filtered again and dried at room temperature.

The samples were compressed into self-supporting pellets and introduced into an Infrared (IR) cell equipped with $\mathrm{KBr}$ windows. The IR measurements were performed at room temperature on a Perkin-Elmer BX FT-IR (Fourier Transformed Infrared) spectrometer at a resolution of $4 \mathrm{~cm}^{-1}$ in the transmission mode. Scanning electron microscopic analyses were taken by using a Zeiss model scanning electron microscope.

\section{RESULTS AND DISCUSSION}

\section{FT-IR analysis results}

Schematic representation of zeolite-2-nitrophenol interaction was given in Figure 1. The excess oxygen in the alumina molecules gives the framework of a negative charge which can be balanced by trapping positively-charged ions (cations) in cages of structure. IR spectra of pure $3 \mathrm{~A}$ zeolite and 2nitrophenol adsorbed on $3 A$ zeolite were given in Figure 2. IR spectra of pure $5 \mathrm{~A}$ zeolite and 2nitrophenol adsorbed on $5 \mathrm{~A}$ zeolite are given in Figure 3. All IR spectral data were summarized in Table 1.

We refer to the work of Chis (2004), Srinivasan et al. (2007), Sundaraganesan et al. (2007), Zych et al. (2007), Clarkson and Smith (2003), Wang et al. (2009), Kovacs et al. (1998), Refat et al. (2007), Sundaraganesan et al. $(2006,2008)$ and Pei et al. (2006) for vibrational assignments of 2-nitrophenol.

The hydroxyl $(\mathrm{OH})$ stretching vibration frequency for pure 2-nitrophenol is observed at $3467 \mathrm{~cm}^{-1}$, This band is observed at 3438 and $3434 \mathrm{~cm}^{-1}$ after 2nitrophenol adsorption on zeolites $3 \mathrm{~A}$ and $5 \mathrm{~A}$, respectively. As can be seen from these results, there are considerable decreases in $\mathrm{OH}$ vibration band for the zeolite complex. The fact that $\mathrm{OH}$ group of 2-nitrophenol and surface silanol groups of zeolites interact with each other through a hydrogen bond can explain the reason of decrease at $\mathrm{OH}$ band vibrations (Öztürk et al., 2009). As a reason for this; $\mathrm{OH}$ group has a weak hydrogen bond with surface silanol groups and decreased force constant of $\mathrm{OH}$ group.

For 2-nitrophenol, asymmetric nitro stretching band was observed at $1532 \mathrm{~cm}^{-1}$. After the adsorption of 2nitrophenol on zeolites $3 \mathrm{~A}$ and $5 \mathrm{~A}$, it was observed at $1533 \mathrm{~cm}^{-1}$ for both the zeolites. Symmetric nitro stretching vibration band for 2-nitrophenol, which was observed at $1312 \mathrm{~cm}^{-1}$, was observed at 1313 and $1312 \mathrm{~cm}^{-1}$, after the adsorption on zeolites $3 \mathrm{~A}$ and $5 A$, respectively. As can be seen in Figure 2 , there is a little frequency changes in asymmetric and symmetric $\mathrm{NO}_{2}$ stretching bands. This gives a clue that interaction between nitrophenol and zeolites cannot occur through $\mathrm{NO}_{2}$.

The C-O stretching vibration band for 2-nitrophenol 


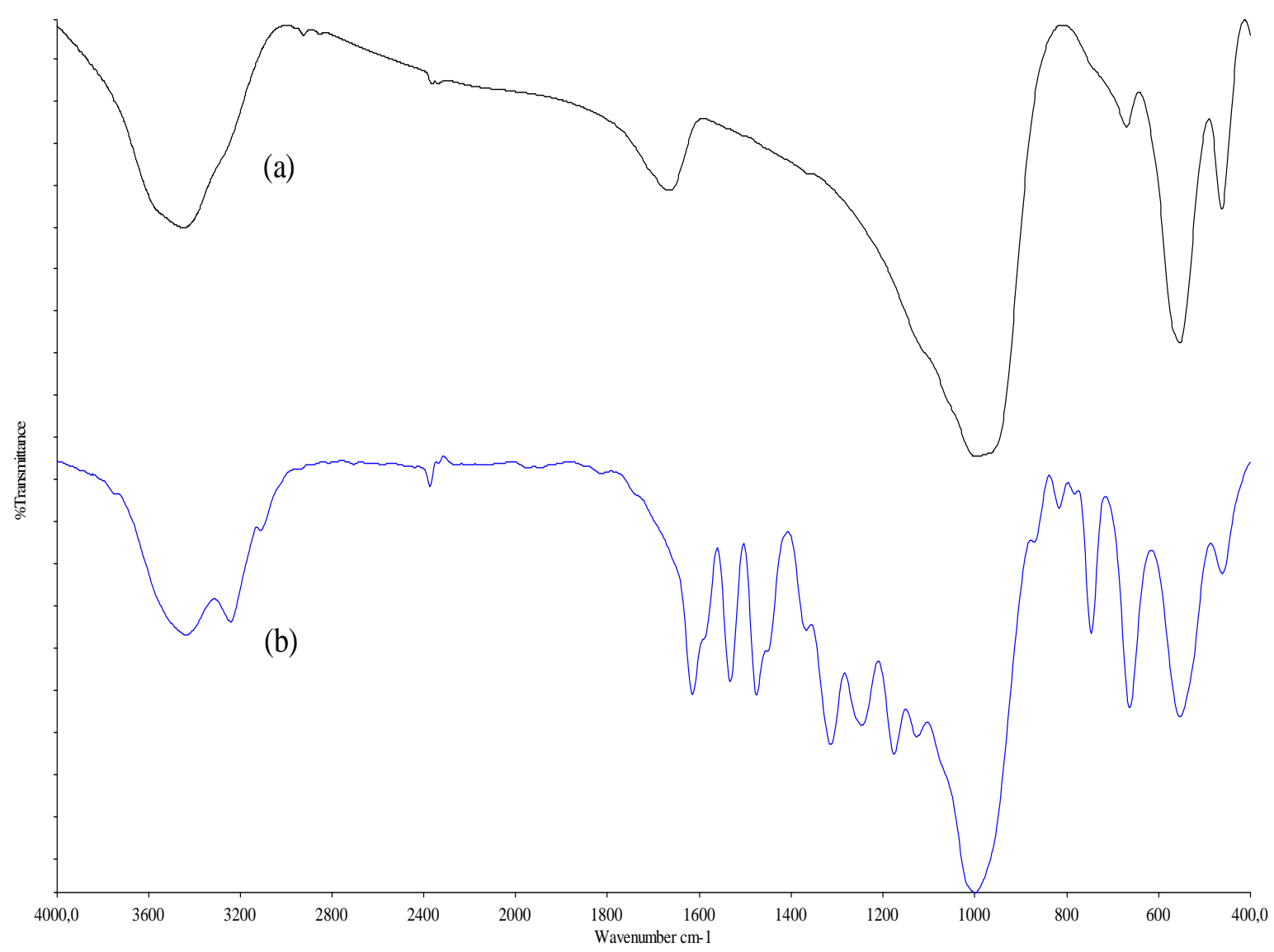

Figure 2. (a) IR spectra of pure 3A zeolite, (b) 2-nitrophenol adsorbed on 3A zeolite.

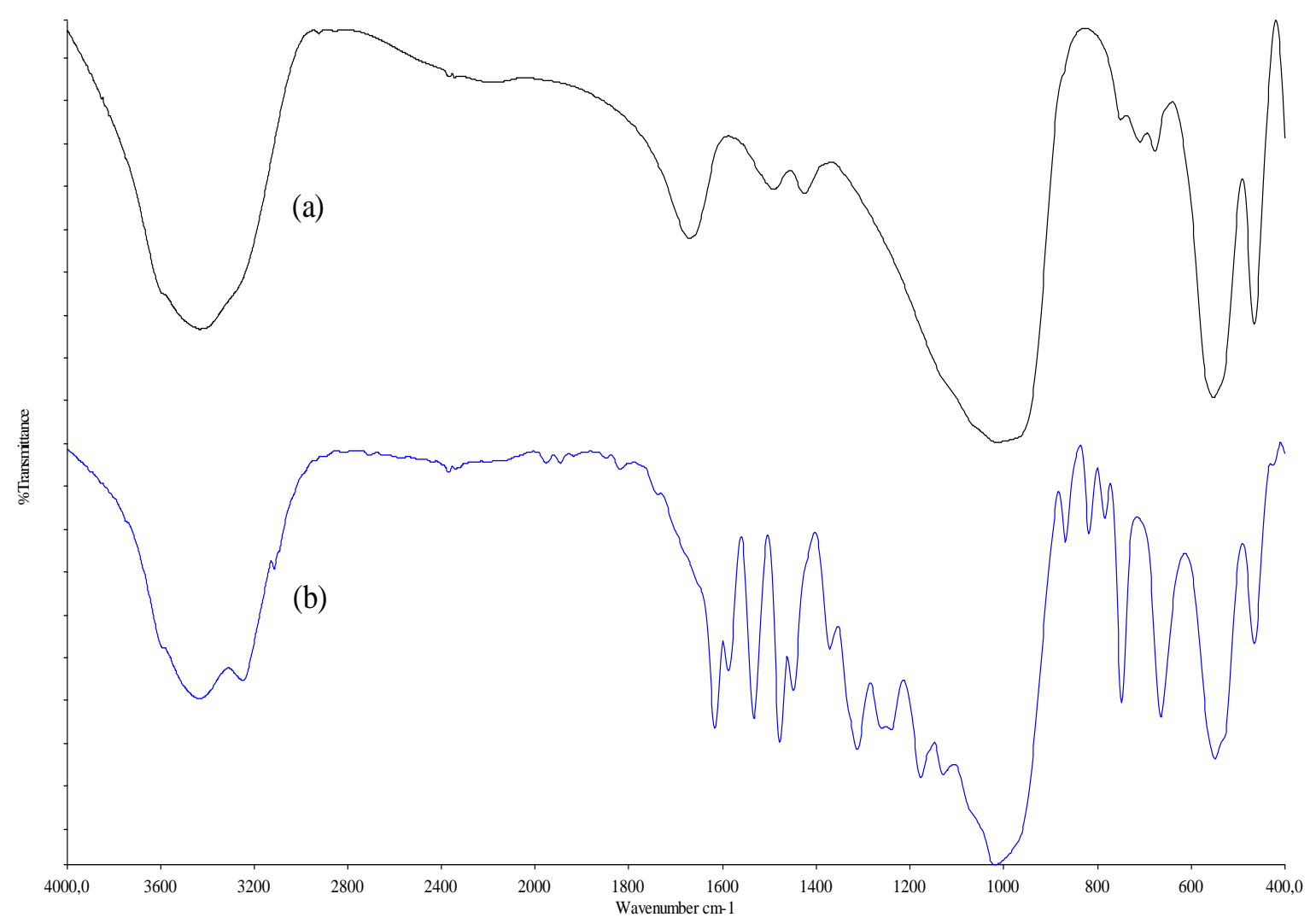

Figure 3. (a) IR spectra of pure 5A, (b) 2-nitrophenol adsorbed on 5A zeolite. 
Table 1. IR results of zeolites +2 -nitrophenol (vibrational frequencies in $\mathrm{cm}^{-1}$ ).

\begin{tabular}{cccc}
\hline 2-nitrophenol & 2-nitrophenol-3A & 2-nitrophenol-5A & Assignments \\
\hline $3467^{\mathrm{w}}$ & $3438^{\mathrm{b}}$ & $3434^{\mathrm{b}}$ & $\mathrm{u}(\mathrm{O}-\mathrm{H})$ \\
$3236^{\mathrm{w}}$ & $3245^{\mathrm{b}}$ & $3248^{\mathrm{b}}$ & $\mathrm{u}(\mathrm{O}-\mathrm{H})$ \\
$3113^{\mathrm{vw}}$ & $3113^{\mathrm{w}}$ & $3114^{\mathrm{w}}$ & $\mathrm{u}(\mathrm{C}-\mathrm{H})$ \\
$3091^{\mathrm{vw}}$ & $3092^{\mathrm{w}}$ & $3094^{\mathrm{sh}}$ & $\mathrm{u}(\mathrm{C}-\mathrm{H})$ \\
$1614^{\mathrm{vs}}$ & $1616^{\mathrm{s}}$ & $1615^{\mathrm{s}}$ & $\mathrm{u}(\mathrm{C}=\mathrm{C})$ \\
$1589^{\mathrm{b}}$ & $1589^{\mathrm{m}}$ & $1587^{\mathrm{m}}$ & $\mathrm{u}(\mathrm{C}=\mathrm{C})$ \\
$1532^{\mathrm{vs}}$ & $1533^{\mathrm{s}}$ & $1533^{\mathrm{vs}}$ & $\mathrm{u}\left(\mathrm{NO}_{2}\right) \mathrm{as}$. \\
$1477^{\mathrm{b}}$ & $1478^{\mathrm{vs}}$ & $1477^{\mathrm{s}}$ & $\mathrm{u}(\mathrm{C}=\mathrm{C})$ \\
$1312^{\mathrm{m}}$ & $1313^{\mathrm{m}}$ & $1312^{\mathrm{s}}$ & $\mathrm{u}\left(\mathrm{NO} \mathrm{O}_{2}\right) \mathrm{s}$. \\
$1266^{\mathrm{w}}$ & - & - & $\beta(\mathrm{C}-\mathrm{H})$ \\
$1236^{\mathrm{w}}$ & $1248^{\mathrm{w}}$ & $1239^{\mathrm{w}}$ & $\mathrm{u}(\mathrm{C}-\mathrm{O})$ \\
$1177^{\mathrm{m}}$ & $1177^{\mathrm{m}}$ & - & $\beta(\mathrm{O}-\mathrm{H})$ \\
$1027^{\mathrm{w}}$ & - & - & $\mathrm{v}(\mathrm{C}-\mathrm{H})$ \\
$868^{\mathrm{m}}$ & $872^{\mathrm{m}}$ & $868^{\mathrm{m}}$ & $\mathrm{v}(\mathrm{C}-\mathrm{H})$ \\
$818^{\mathrm{m}}$ & $816^{\mathrm{s}}$ & $817^{\mathrm{s}}$ & $\beta\left(\mathrm{NO} \mathrm{O}_{2}\right)$ \\
$784^{\mathrm{m}}$ & $784^{\mathrm{m}}$ & $784^{\mathrm{m}}$ & $\mathrm{v}(\mathrm{C}-\mathrm{H})$ \\
$748^{\mathrm{b}}$ & $748^{\mathrm{vs}}$ & $748^{\mathrm{vs}}$ & $\mathrm{w}\left(\mathrm{NO} \mathrm{O}_{2}\right)$ \\
$664^{\mathrm{vs}}$ & - & - & $\beta(\mathrm{CCC})$ \\
\hline
\end{tabular}

$U=$ strecthing; $\delta=$ bending; $\beta=$ in plane bending; $v=$ out of plane bending; $\omega=$ wagging; as = asymmetric; $\mathrm{s}=$ symmetric; $\mathrm{vs}=$ very strong; $\mathrm{s}=$ strong; $\mathrm{m}=$ medium; $\mathrm{w}=$ weak; $\mathrm{vw}=$ very weak; $\mathrm{sh}=$ shoulder; $\mathrm{b}=$ broad.
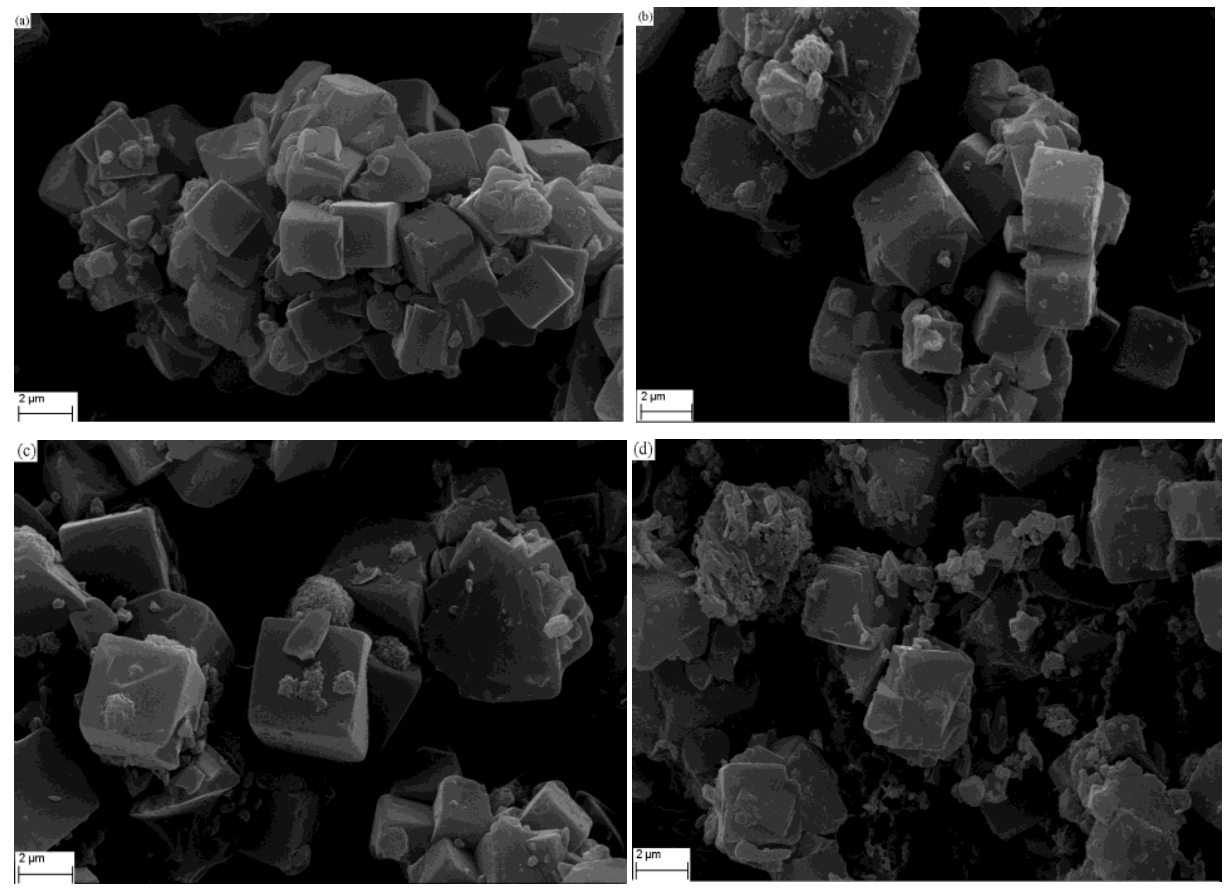

Figure 4. SEM images of (a) pure $3 \mathrm{~A}$ zeolite, (b) pure 5A zeolite, (c) 2-nitrophenol and $3 \mathrm{~A}$ zeolite, (d) 2-nitophenol and 5A zeolite.

is observed at $1236 \mathrm{~cm}^{-1}$, this band is observed at $1248 \mathrm{~cm}^{-1}$ after the adsorption on zeolite $3 \mathrm{~A}$ of 2 nitrophenol and at $1239 \mathrm{~cm}^{-1}$ after the adsorption on zeolite $5 \mathrm{~A}$ of 2-nitrophenol. So, there are red frequency shifts on $\mathrm{C}-\mathrm{O}$ stretching vibration band for 2-nitrophenol adsorbed on $3 \mathrm{~A}$ and $5 \mathrm{~A}$ zeolites, respectively.

\section{Scanning electron microscopy (SEM) results}

SEM images of samples were given in Figure 4. The images of pure zeolites $3 \mathrm{~A}$ and $5 \mathrm{~A}$ and those taken after the 2-nitrophenol adsorption show the structures. Cubic forms of zeolite $3 \mathrm{~A}$ and zeolite $5 \mathrm{~A}$ are observed in their naked state. The SEM images 
of zeolites after adsorption of 2-nitrophenol on zeolites predicated that no impressive results were obtained in the scale of $2 \mu \mathrm{m}$. Cubic forms of zeolites still stay in the same shape. After the adsorption, it is possible to talk about no formational change on the surface of the zeolites. This result can be attributed to stable zeolite surface after adsorption.

\section{Conclusion}

From these results we can say that the $\mathrm{OH}$ group of the 2-nitrophenol interacts with the silanol groups on zeolites $3 \mathrm{~A}$ and $5 \mathrm{~A}$. The interaction reveals the existence of a hydrogen bond between them. After the adsorption, there are blue frequency shifts for $\mathrm{OH}$ groups of 2-nitrophenol adsorbed on zeolite $3 \mathrm{~A}$ and $5 A$, respectively. In zeolites, the oxygen atom of Si$\mathrm{O}-\mathrm{Si}$ bond, acts a hydrogen bond acceptor, which tends to make a bond of $\mathrm{OH}$ part of 2-nitrophenol.

FT-IR spectroscopy was used to study the molecular scale interaction of nitrophenol compound with sorbent. Little change was observed in vibrations of nitro group after the adsorption. These data can be explained that $-\mathrm{NO}_{2}$ functional group has no effect in adsorption process.

The results are very important for the application of zeolites as sorbent for the adsorption of organic pollutants from environment. Results show that LTA type synthetic ( $3 A$ and $5 A$ ) zeolites are effective sorbents for the removal of 2-nitrophenol.

\section{REFERENCES}

Abburi K (2003). Adsorption of Phenol And P -Chlorophenol from Their Single and Bisolute Aqueous Solutions on Amberlite Xad16 Resin. J. Hazard. Mater. B105:143-156.

Abu-Lail LI (2010). Removal Of Chloroform And Mtbe From Water By Adsorption Onto Granular Zeolites: Equilibrium, Kinetic, And Mathemaiical Modeling Study. PhD dissertation, Worcester Polytechnic Institute, Worcester, USA.

Bardakçi B, Kaya N (2009). FT-IR Spectroscopic Study of Triethyl Phospate Adsorption on FAU type zeolites. Asian J. Chem. 21(6):4914-4918.

Chiş V (2004). Molecular and Vibrational Structure of 2,4Dinitrophenol: FT-IR, FT-Raman and Quantum Chemical Calculations. Chem. Phys. 300:1-11.

Clarkson J, Smith WE (2003). A DFT Analysis of the vibrational spectra of nitrobenzene. J. Mol. Struct. 655:413-422.

Dargaville TR, Looney MG, Solomon HD (1996). The Adsorption of Multinuclear Phenolic Compounds on Activated Carbon. J. Colloid Interf. Sci. 182:17-25.

Denizli A, Özkan G, Uçar M (2001). Removal of Chlorophenols from Aquatic Systems with Dye-Affinity Microbeads. Sep. Purif. Technol. 24:255-262.

Dutta S, Basu JK, Ghar RN (2001). Studies on Adsorption of PNitrophenol on Charred Saw-Dust. Sep. Purif. Technol. 21:227235.
Ely A, Baudu M, Basly J, Ould M, Sid'Ahmed OK (2009). Copper and nitrophenol pollutants removal by Namontmorillonite/alginate microcapsules. J. Hazard. Mater. 171:405-409.

Furuya EG, Chang HT, Miura Y, Noll KE (1997). A Fundamental Analysis of the Isotherm for the Adsorption of Phenolic Compounds on Activated Carbon. Sep. Purif. Technol. 11(2):6978.

Kovacs A, Izvekov V, Keresztury G, Pongor G (1998). Vibrational Analysis of 2-Nitrophenol. A Joint FT-IR, FT-Raman and Scaled Quantum Mechanical Study. Chem. Phys. 238:231-243.

Ku Y, Lee KC (2000). Removal of Phenols from Aqueous Solution by XAD-4 Resin. J. Hazard. Mater. B80:59-68.

Little LH (1966). Infrared Spectra of Adsorbed Species, London, Academic Press. P. 352.

Öztürk N, Ucun F, Muhtar, AD, Bahçeli S (2009). Infrared and SEM Analyses of Polyethyleneglycol-400 Adsorbed on Zeolites NaA, $\mathrm{CaA}, \mathrm{NaX}$ and $\mathrm{NaY}$. J. Mol. Struct. 922:35-38.

Pei Z, Shan X, Wen B, Zhang S, Yan L, Khan SU (2006). Effect of Copper on the Adsorption of p-Nitrophenol onto Soils. Environ. Pollut. 139:541-549.

Pi Y, Zhang L, Wang $J$ (2007). The formation and influence of hydrogen peroxide during ozonation of para-chlorophenol. J. Hazard. Mater. 141:707-712.

Refat MS, Killa HMA, Grabchev I, El-Sayed MY (2007). Synthesis and Characterization of N,N-Bis[2-Hydroxyethyl]-1,4,6,8Naphthalenediimide with Para Substituted of Phenols Based on Charge-Transfer Complexes. Spectrochim Acta A68:123-133.

Shen YH (2002). Removal of Phenol from Water by AdsorptionFlocculation Using Organobentonite. Water Res. 36:1107-1114.

Shu HT, Li D, Scala AA, Ma YH (1997). Adsorption of Small Organic Pollutants from Aqueous Streams by AluminosilicateBased Microporous Materials. Sep. Purif. Technol. 11:27-36.

Srinivasan P, Kanagasekaran T, Vijayan N, Bhagavannarayana G, Gopalakrishnan R, Ramasamy P (2007). Studies on the Growth, Optical, Thermal and Dielectric Aspects of A Proton Transfer Complex - Dimethyl Amino Pyridinium 4-Nitrophenolate 4Nitrophenol (Dmapnp) Crystals for Non-Linear Optical Applications. Opt. Mater. 30:553-564.

Sundaraganesan N, Anand B, Joshua BD (2006). FTIR, FTRaman Spectra and Ab Initio DFT Vibrational Analysis of 2,4Dichloro-6-Nitrophenol. Spectrochim. Acta A65:1053-1062.

Sundaraganesan N, Meganathan C, Anand B, Lapouge C (2007). FT-IR, FT-Raman spectra and ab initio DFT vibrational analysis of $p$-bromophenoxyacetic acid. Spectrochim. Acta A66:773-780. Sundaraganesan N, Meganathan C, Karthikeyan B (2008). FT-IR, FT-Raman Spectra and Quantum Chemical Calculations of Some Chloro Substituted Phenoxy Acetic Acids. Spectrochim. Acta A70:430-438.

Wang GX, Gong, XD, Liu Y, Xiao HM (2009). A theoretical study on the vibrational spectra and thermodynamic properties for the nitro derivatives of phenols. Spectrochim. Acta A74:569-574

Zych T, Misiaszek T, Szostak MM (2007). Polymorphism of 2Nitroaniline Studied by Calorimetric (DSC), Structural (X-ray diffraction) and Spectroscopic (FT-IR, Raman, UV-Vis) Methods. Chem. Phys. 340:260-272. 